TITLE:

\title{
Lernanthropids and Lernaeopodids (Copepoda) Parasitic on Australian Bream (Acanthopagrus spp.)
}

$\operatorname{AUTHOR}(\mathrm{S})$ :

Byrnes, Thomas

CITATION:

Byrnes, Thomas. Lernanthropids and Lernaeopodids (Copepoda) Parasitic on Australian Bream (Acanthopagrus spp.). PUBLICATIONS OF THE SETO MARINE BIOLOGICAL LABORATORY 1988, 33(1-3): 97-120

ISSUE DATE:

1988-08-20

URL:

http://hdl.handle.net/2433/176147

RIGHT: 


\title{
Lernanthropids and Lernaeopodids (Copepoda) Parasitic on Australian Bream (Acanthopagrus spp.)
}

\author{
By
}

\section{Thomas Byrnes}

Cayman Island Marine Laboratory, P.O. Box 596, Grand Cayman, B.W.I.

With Text Figures $1-12$ and Tables $1-9$

\begin{abstract}
Three lernanthropids and three lemaeopodids are recorded from Australian bream, i.c. Acanthopagrus butcheri (Munro), A. australis (Gunther), A. berda (Forrskal), and A. latus (Houttuyn), from around Australia. Lernanthroputs sp. is described; L. chrysophrys Shishido and L. atrox Heller are redescribed with the male of $L$. chrysophyys recorded for the first time. The lernaeopodids include Alella macrotrachelus (Brian), Clavellopsis parasargi Roubal, and Neobrachiella lata (Song et Chen). The zoogeography and host specificity of all parasites is described.
\end{abstract}

From May, 1982 to January, 1983, I collected and examined approximately 1000 Acanthopagrus specimens from all around Australia in order to assess the ectoparasite fauna of this economically important group of fishes.

The only previous lernanthropid and lernaeopodid records from Australian waters are those given in Heegaard (1940, 1962), Kabata (1968, 1979a), Cressey \& Collette (1970), Walker (1973), Roubal (1981) and Roubal et al. (1983).

All fish were collected between May 1982 and January 1983. Fish were collected by hook, some by net and a few with a hand spear. Samples of at least forty fish per species, per site were collected at the localities shown in Fig. 11.

Immediately after capture, fish were killed by pithing, their ventral side slit open, and they were dropped into $10 \%$ formalin. The body surface, fins, head, nares, mucous cavities, pseudobranchs, individual gill filaments and gill arches of each fish were examined under a dissecting microscope. The sediment resulting from dissection and that left in the drum containing the preserved fish were also examined.

Specimens were taken from $10 \%$ formalin and washed in distilled water before being stored in $70 \%$ ethanol. All parasites were cleared, dissected and examined in lactic acid. Standard cavity slides were used to hold specimens being measured in order to reduce compression by the coverslip.

Parasites were measured with a calibrated ocular micrometer. Measurements are given in micrometers $(\mu \mathrm{m})$ as mean (range), length $\times$ width. All drawings were made with the aid of a camera lucida.

Prevalence is defined as the percentage of individuals of a host infected with a particular parasite species. Relative density is defined as the total number of individuals of a particular parasite species in a sample of hosts - total number of individuals of the host species (infected and uninfected) in the sample examined (see Margolis et al., 1982)

Publ. Seto Mar. Biol. Lab., 33 (1/3), 97-120.

(Article 5) 


\section{Genus Lernanthropus Blainville}

\section{Lernanthropus sp.}

(Fig. 1)

Material examined. Two specimens recovered. Host: A. australis and A. berda. Site: Middle of gill filaments. Localities: Yeppoon and Townsville. See Table 7 for prevalence and relative densities; Fig. 11 for distribution.

Female (Fig. 1 A-J). Measurements based on one specimen from Yeppoon. Yellow to white in preserved specimens. Total length (from anterior tip of cephalothorax to posterior tip of caudal ramus) 1585. Cephalothorax (Fig. 1A) $670 \times 670$, with dorsal shield somewhat flattened, only slightly wider posteriorly, sides nearly parallel; small posterolateral lobes; posterior margin virtually straight. Dorsal plate 555 wide, about as long as wide, circular in outline, and completely concealing genital complex, abdomen and portion of caudal ramus. Caudal rami (Fig. 1F) $257 \times 58$, well developed, tapered posteriorly, armed with three setules; two long anterodorsal setae and one short terminal setae.

First antenna (Fig. 1H) elongate, cylindrical, indistinctly segmented, apically armed with ten naked setae; close to base, two-segmented flagellum. Second antenna (Fig. 1B) very large, bases of both antennae connected across center by heavily sclerotized plate. Corpus broad and long, about two-thirds length of cepalothoracic shield; subchela not divided into shaft and claw, armed with one flattened subtriangular spine near inner, basal corner (Fig. 1B).

Mouth tube conical, with broad base and tapering tip. Mandible siphonostome, two-segmented, with tip curving to fit inner contour of mouth, dentiferous margin bearing seven sharp denticles.

First maxilla (Fig. 1C) with subcylindrical endopod, widest near center, with three short, subequal terminal processes; exopod much smaller, with slightly inflated base and short terminal process. Second maxilla (Fig. 1I) with stout laceratus, unarmed; brachium long, cylindrical, laterally armed on posterior margin with large denticles and a large, sharp process emerging from dorsal aspect; terminal claw with two rows of posteriorly directed denticles. Maxilliped subchelate; corpus robust, unarmed; subchela (Fig. 1J) With curving shaft and bluntly tipped curving claw.

First leg (Fig. 1E) biramous; exopod quadrate, curving inwards, with five stout terminal spines and several terminal denticles; endopod tapering, apically denticulated, with single long, apical seta; sympod with short, sharp process medial to base of exopod.

Second leg (Fig. 1G) without sympodial process medial to exopod but with additional small setule next to seta which is lateral to exopod; exopod quadrangular with four large and one short terminal spine and single row of apical denticles; endopod tapering, apical half denticulated with terminal seta (shorter than that of first leg).

Third leg (Fig. 1D) broad and long, foliaceous, emerging near tip of second leg, 


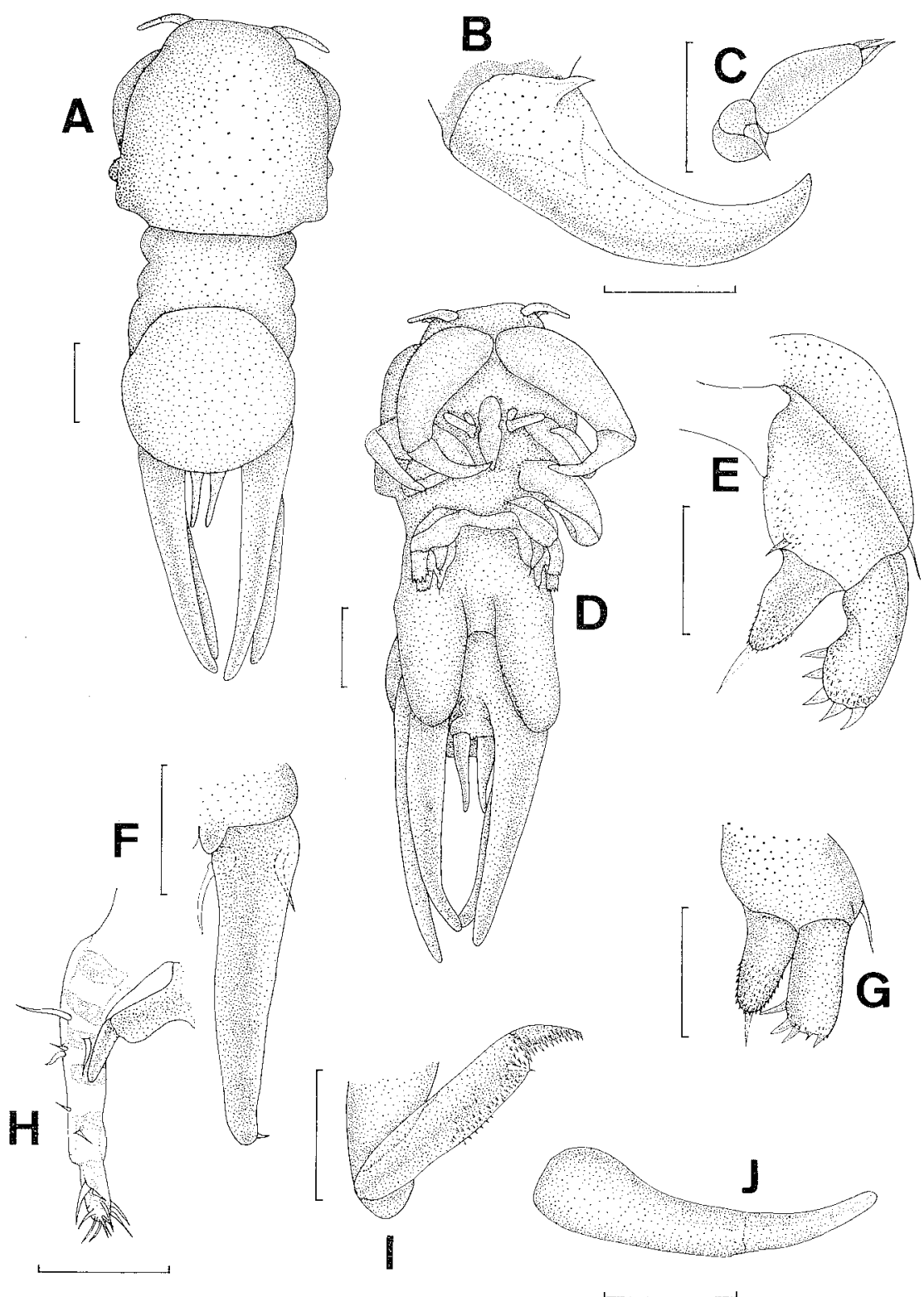

Fig. 1. Lernanthropus sp. Female. A. Habitus, dorsal; B. Distal segment of second antenna, ventral; C. First maxilla, ventral; D. Habitus, ventral; E. First leg, ventral; F. Caudal ramus, ventral; G. Second leg, ventral; H. First antenna, ventral; I. Second. antenna, ventral; J. Distal portion of maxilliped, ventral. Scale lines: A, D, $250 \mu \mathrm{m}$; B, C, E-G, I, J, $100 \mu \mathrm{m} ; \mathrm{H}, 75 \mu \mathrm{m}$. 
apex well rounded. Fourth leg (Fig. 1D) long, bifid, more than half its length protruding from under dorsal plate. Fifth leg not observed.

Male not found.

Remarks. I am hesitant to assign a name to this species for it may be a juvenile as Kabata (pers. comm.) has indicated. This view is based on the following: (a) the parasite has no egg sacs, (b) it has unusually large first and second legs (normally they are relatively much smaller) and (c) the habitus is top-heavy, with the anterior part of the body dominating. In addition to the above the parasite is very small (less than $2 \mathrm{~mm}$ ).

This species is very rare, of over 1000 fish examined in 1982 only one specimen was found. Another specimen was acquired from the Townsville area in 1980. Perhaps it displays a stronger affinity for a different group of hosts and its occurrence on Acanthopagrus is merely fortuitous.

Differential diagnosis. Lernanthropus sp. differs from other species in the relatively large sized second antenna and in the relatively large dorsal shield which is larger than the dorsal plate.

\section{Lernanthropus chrysophys Shishido}

\section{(Figs 2 \& 3)}

Lernanthropus chrysophys Shishido, 1898, pp. 337-340, fig. 104: Yamaguti, 1936, pp. 15-16, pl. 9, figs 92-97; Shiino, 1955, pp. 62-64, fig. 5; Tripathi (1959 (1962)), pp. 202-203, fig. 26.

Material examined. One hundred female and twenty-four male specimens collected. Three males from A. berda, at Darwin, deposited in Australian Museum (P35466). Hosts: A. australis, A. berda and $A$. latus. Site: Middle to base of gill filaments. Localities: Eden, Brisbane, Gladstone, Yeppoon, Townsville, Lucinda, Bing Bong, Darwin, Broome, and Point Samson. See Table 7 for prevalence and relative densities; Fig. 11 for distribution.

Previous records. Shishido (1898) acquired female specimens from Acanthopagrus macrocephalus at Misaki. Yamaguti (1936) obtained 6 females from A. longispinis (Temm. et Schleg.) from the Inland Sea of Japan, 1927. Shiino (1955) collected two females at Tomioka, Amakusa Island From A. macrocephalus. Tripathi (1959 (1962)) recorded the female from A. berda in India. Markevitch \& Titar (1975) recorded the female (host not given) from the Soviet Far East. Females were also recovered from A. macrocephalus in China by Song \& Chen (1976) and Song \& Kuang (1980). No males of this species have been recorded.

Female (Fig. 2 A-L). Measurements based on ten specimens from Townsville. For additional measurements see Table 1. Most specimens dark red in preservative. Total body length (measured from anterior tip of cephalothorax to end of caudal ramus) 3176 (2550-3570). Cephalothorax (Fig. 2A) 1044 (870-1120) ×1585 (1390$1650)$, with dorsal shield narrower anteriorly, sides produced into huge posterolateral flanges, anterolateral margins extended ventrally as prominent, rounded anterolateral corners; concave anterior margin, convex posterior margin. Dorsal plate 1314 (1020-1550) wide, longer and wider than anterior region, circular in outline, and completely concealing genital complex, abdomen and caudal rami from dorsal aspect. 


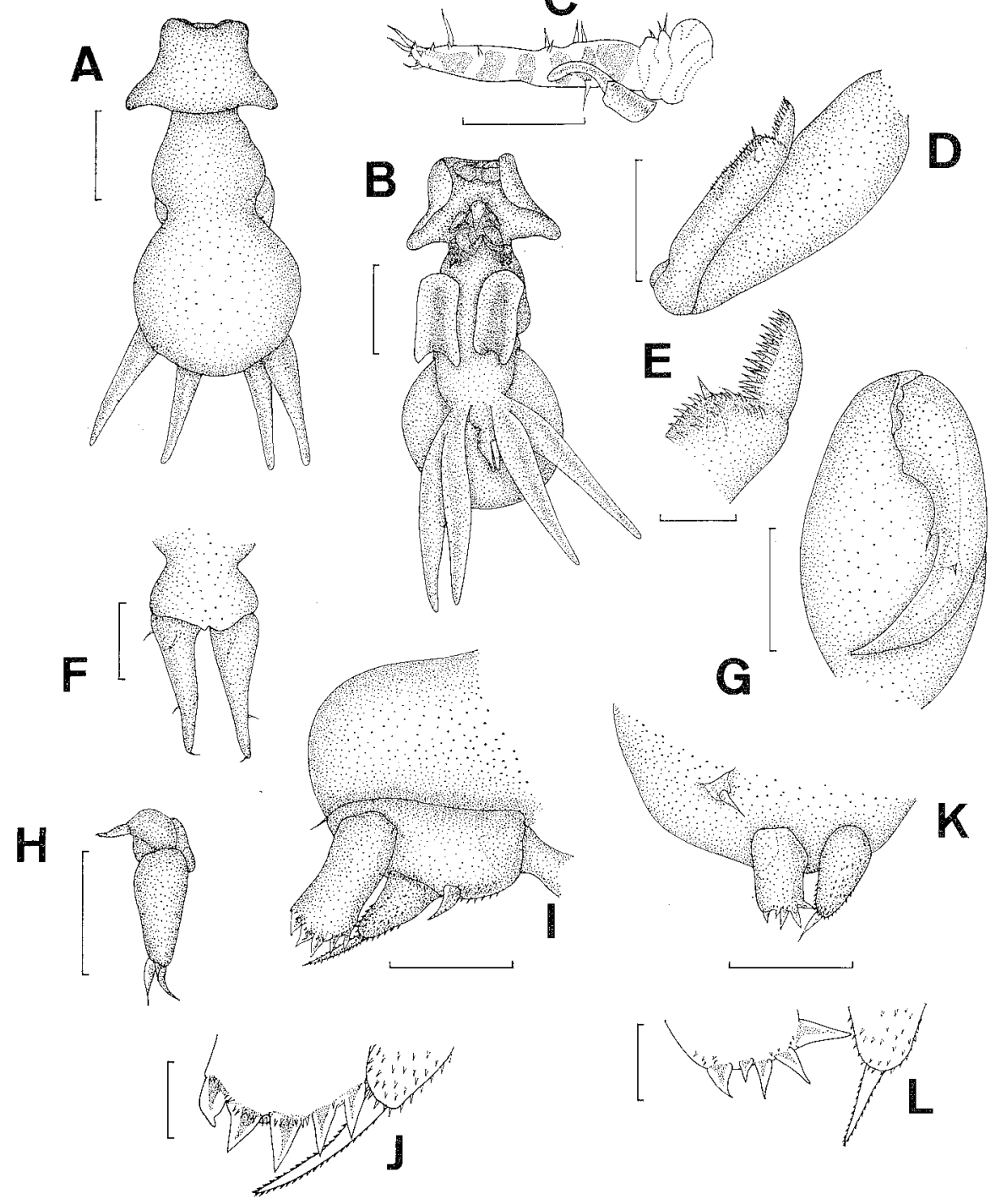

Fig. 2. Lernanthropus chrysophrys Shishido. Female: A. Habitus, dorsal; B. Habitus, ventral; C. First antenna, ventral; D. Second maxilla, ventral; E. Tip of second maxilla, ventral; F. Abdomen and caudal ramus, ventral; G. Maxilliped, ventral; H. First maxilla, ventral; I. First leg, ventral; J. Tip of first exopod and endopod, ventrai; K. Second leg, ventral; L. Tip of second exopod and endopod, ventral. Scale lines: A, B, $800 \mu \mathrm{m} ; \mathrm{C}, \mathrm{D}, \mathrm{G}, \mathrm{H}, \mathrm{I}, \mathrm{K}, 100 \mu \mathrm{m} ; \mathrm{E}, \mathrm{J}, \mathrm{L}, 25 \mu \mathrm{m} ; \mathrm{F}, 250 \mu \mathrm{m}$.

Genital complex small, indistinctly separated from pregenital area and abdomen. Abdomen shorter and narrower than preceding segment, widest posteriorly. Caudal ramus (Fig. 2F) $384(350-410)$ long, tapering posteriorly; armed with four setules; one anterodorsal, one anterolateral, one subterminal and one terminal.

First antenna (Fig. 2C) short, cylindrical, segments fused; apically armed with 
Table 1. Measurements (mean (range)) of Lernanthropus chrysophrys on three species of Acanthopagrus at various localities.

( $\mathrm{L}=$ maximum length; $\mathrm{W}=$ maximum width; $\mathrm{N}=$ number of specimens measured). For abbreviations of localities see Fig. 11.

\begin{tabular}{|c|c|c|c|c|}
\hline \multirow{2}{*}{$\begin{array}{l}\text { Host } \\
\text { Localities }\end{array}$} & & \multicolumn{3}{|c|}{ A. berda } \\
\hline & & $\mathrm{Y}(\mathrm{N}=10)$ & $\mathrm{BB}(\mathrm{N}=10)$ & $\mathrm{DW}(\mathrm{N}=10)$ \\
\hline Total & $\mathrm{L}$ & $2554(1840-3610)$ & $3139(2650-3570)$ & $3229(2860-3610)$ \\
\hline \multirow[t]{2}{*}{ Cephalothorax } & $\mathbf{L}$ & $847(650-1020)$ & $951 \quad(860-1080)$ & $963(890-1020)$ \\
\hline & W & $1103(860-1290)$ & $1448(1330-1630)$ & $1412(1120-1630)$ \\
\hline Dorsal plate & $\mathrm{W}$ & $1324(1020-1550)$ & $1491(1020-1650)$ & $1590(1410-2040)$ \\
\hline Host & & \multicolumn{2}{|c|}{ A. latus } & A. australis \\
\hline Localities & & $\mathrm{BM}(\mathrm{N}=10)$ & $\operatorname{PS}(N=10)$ & $\mathrm{T}(\mathrm{N}=10)$ \\
\hline Total & $\mathrm{L}$ & $3153(2650-3630)$ & $2923(2650-3160)$ & $3176(2550-3570)$ \\
\hline \multirow[t]{2}{*}{ Cephalothorax } & $\mathrm{L}$ & $970(920-1060)$ & $938(820-1060)$ & $1044(920-1120)$ \\
\hline & W & $1484(1310-1630)$ & $1380(1220-1530)$ & $1416(1290-1550)$ \\
\hline Dorsal plate & W & $1611(1220-2140)$ & $1441(1220-1630)$ & $1337(1020-1530)$ \\
\hline
\end{tabular}

ten naked setae; two-segmented flabellum close to base. Second antennae prehensile, robust, bases connected across center by heavily sclerotinized plate. Corpus muscular with curving subtriangular process on inner margins; subchela not divided into shaft and claw, armed with two flattened subtriangular spines, one near inner basal corner, other with curved tip, immediately distal on medial margin.

Mouth tube conical, with broad base and tapering tip. Mandible siphonostome, two-segmented, with tip curving to fit inner contour of mouth; dentiferous margin bearing seven pointed denticles.

First maxilla (Fig. 2H) with inflated base; endopod subcylindrical, slightly tapering distally, with three terminal processes, two of about equal length separated by a third of about half this length, all armed with minute denticles. Exopod much smaller, with inflated base and short, sturdy process armed with minute denticles. Second maxilla (Fig. 2D) with stout lacertus, unarmed; brachium long, cylindrical, distoventrally armed on posterior margin with large denticles and pointed process on dorsal side; terminal claw (Fig. 2E) with two neat rows of large denticles on posterior margin. Maxilliped (Fig. 2G) subchelate; corpus robust, suboval; subchela with stout curving shaft, armed with distolateral narrow process and small subtriangular process near base of claw; claw long, strong and curving.

First leg (Fig. 2I) biramous; exopod quadrate, with five stout terminal spines and a single row of terminal denticles (Fig. 2J); endopod tapering, denticulated (especially apically), with single long, apical seta, armed with minute denticles; sympod with pointed, stout process and two rows of denticles medial to base of endopod, short thin seta, lateral to base of exopod. Second leg (Fig. 2K) without sympodial process medial to endopod; exopod with five spines and several small denticles (Fig. 2L); endopod apically armed with denticles and single denticulated 
seta, about half length of first leg counterpart (Fig. 2J). Third leg (Fig. 2B) broad and long, foliaccous, emerging from posterior half of pregenital segment, projecting ventrally in form of arc, lateral margins curved inwards, forming deep groove on posterior side, apex rounded. Fourth leg (Fig. 2B) bifid, longest pod 2084 (13302860), lanceolate, about half its length protruding from under dorsal plate. Fifth leg apparently lacking.

Male (Fig. 3 A-L). Measurements based on ten specimens from Darwin. White to yellow in colour. Total length (from anterior tip of carapace to posterior tip of caudal ramus) $1470(1270-1780)$. Cephalothorax (Fig. 3A) $614(498-780) \times 531$ (457-624), with a somewhat flattened dorsal shield, widest in its anterior half, evenly tapering posteriorly, laterally and dorsally armed with small round protuberances. Genital complex large, widest anteriorly, pyriform, indistinctly separated from pregenital segment and abdomen. Abdomen short and narrow, triangular. Caudal ramus (Fig. 3G) 224 (199-282) long, well developed, armed as in female.

First antenna (Fig. 3G) cylindrical, indistinctly seven-segmented, apically armed with eleven naked setae; two-segmented flagellum close to base. Second antennae (Fig. 3H) prehensile with powerful corpus, armed as in female. Circular, folded protuberance near base of second antenna (Fig. 3B).

First maxilla (Fig. 3E) with subcylindrical endopod, slightly tapering distally, with three terminal processes, two of about equal length, central one about one-third longer than others, denticulated inner margin; exopod (Fig. 3F) small, denticulated, with short, sturdy process armed on both margins with minute denticles. Second maxilla (Fig. 3D) similar to that of female. Maxilliped (Fig. 3I) with heavily denticulated corpus and without small medial process near base of claw as found in female.

First leg (Fig. $3 \mathrm{~J}, \mathrm{~K}$ ) as in female. Second leg (Fig. 3L) biramous; exopod modified, latter with peduncular base, broad distally, with circular cavity at apex fringed with many denticles and two larger subtriangular spines. Third leg (Fig. 3B) unsegmented, bifid, medial lobe much shorter than lateral one. Fourth leg (Fig. 3B) resembling that of female. Both legs covered by small, rounded protuberances.

Remarks. Redescription of the female is necessary because the previous descriptions of this species by Shishido (1898), Yamaguti (1936) and Shiino (1955) are inadequate and conflicting. Yamaguti improved on Shishido's original description but described only a minimum of details. Shiino believed Yamaguti's material was poorly prepared. Yamaguti's description of the second maxilla is similar to mine but he does not show an obvious dorsal process as is shown in the description above. Shiino shows the process but he also depicts two margins of the claw as denticulated whilst I see only one. Neither author observed a spine on the subchela of the second antenna though it is clearly present in my material. Shiino shows only four terminal spines on the second exopod while Yamaguti and I show five. Shiino shows endopod of the first maxilla tipped by only two processes but there are three in my material; Yamaguti does not mention these processes. 


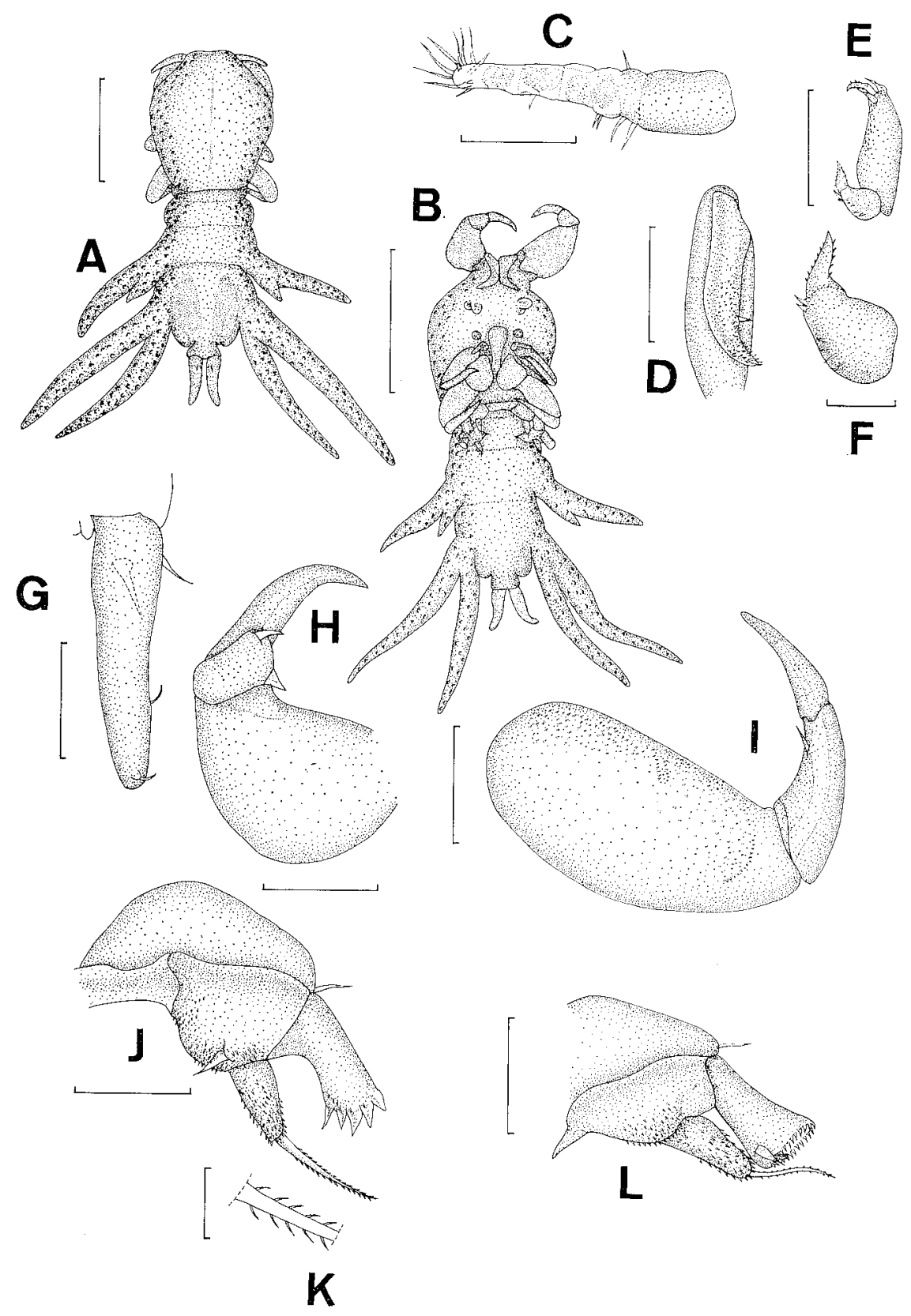

Fig. 3. Lernanthropus chrysophrys Shishido. Male: A. Habitus, dorsal; B. Habitus, ventral; C. First antenna, ventral; D. Second maxilla, ventral; E. First maxilla, ventral; F. Exopod of first maxilla, ventral; G. Caudal rami, ventral; H. Second antenna, ventral; I. Maxilliped, ventral; J. First leg, ventral; K. Portion of first endopod terminal spine; L. Second leg, ventral. Scale lines: A, B, $500 \mu \mathrm{m} ; \mathrm{C}, \mathrm{D}, \mathrm{E}, \mathrm{G}, \mathrm{H}, \mathrm{I}$, $\mathrm{J}, \mathrm{L}, 100 \mu \mathrm{m} ; \mathrm{F}, \mathrm{K}, 25 \mu \mathrm{m}$. 
Taking into consideration the combination of Shishido's, Yamaguti's, and Shiino's descriptions along with the fact that their specimens were collected from very closely related (congeneric) hosts, I am certain that my material is conspecific with L. chrysophrys.

It is interesting to note that the males were found with much less frequency than their female counterparts. Perhaps this is why the male is described here for the first time.

Differential diagnosis. The male differs from all other species in the shape of the carapace, the armature of the second leg, and the small rounded protuberances covering legs three and four as well as a portion of the rest of the body.

\section{Lernanthropus atrox Heller}

(Figs 4 \& 5)

Lernanthropus atrox Heller, 1865, p. 21, Fig. 3: Heider, 1879, pp. 80-81, pl. 4, figs 59-61; Shishido, 1898, pp. 216-218, 254-256, 6 figs; Yamaguti, 1936, pp. 16-17, figs 98-105, pl. 9; Shiino, 1955, pp. 56-61, figs 3-4; Roubal, 1981, pp. 33-35, figs 171-182; [Non] L. atrox Heller, Bassett-Smith, 1898.

Material examined. Eighty-five female and fifty-two male specimens collected. Hosts: $A$. butcheri, A. latus, and A. australis. Site: Distal half of gill filaments. Localities: Eden, Newcastle, Coffs Harbour, Brisbane, Broome, and Carnarvon. See Table 7 for prevalence and relative densitics; Fig. 11 for distribution.

Previous records. Originally described from. Australian seas by Heller (1865) from Pagrosomus unicolor (Q. \& G.), redescribed and figured by Heider (1879). Shishido (1898) described it from $A$. macrocephalus and Pagrosomus major (T. \& S.) in Tokyo Bay. Yamaguti (1936) redescribed Japanese material from Pagrosomus unicolor from the Inland Sea of Japan. Shiino $(1955,1959)$ recorded specimens from A. macrocephalus and P. major at Monotori, Mie Prefecture, Japan, and Kabata (1979a) recorded L. atrox from A. australis at Moreton Bay, Queensland, Australia. Tripathi (1959 (1962)) recovered this parasite from Indian fish, Song \& Chen (1976) and Song \& Kuang (1980) collected it from A. macrocephalus in China, and Roubal (1981) from A. australis at Coffs Harbour, N.S.W.

Female (Fig. 4 A-M). Measurements based on ten specimens from Brisbane. See Table 2 for additional measurements. Preserved specimens red to white. Total length 2562 (2410-2690). Cephalothorax (Fig. 4B) 1024 (820-1220) ×1023 (780-

Table 2. Measurements (mean (range)) of Lernanthropus atrox o from two species of Acanthopagrus at various localities. $(\mathrm{L}=$ maximum length; $\mathrm{W}=$ maximum width; $\mathrm{N}=$ number of specimens measured). Measurements of specimens from $\mathrm{CH}$ are according to Roubal (1981). For abbreviations of localities see Fig. 11.

\begin{tabular}{|c|c|c|c|c|c|}
\hline \multirow{2}{*}{$\begin{array}{l}\text { Host } \\
\text { Localities }\end{array}$} & & \multirow{2}{*}{$\begin{array}{l}\text { A. butcheri } \\
\mathrm{E}(\mathrm{N}=10)\end{array}$} & \multicolumn{3}{|c|}{ A. australis } \\
\hline & & & $N(N=10)$ & $\mathrm{CH}(\mathrm{N}=12)$ & $B(N=10)$ \\
\hline Total & $\mathbf{L}$ & $2484(2250-2800)$ & $2300(2040-2450)$ & $2980(2150-3150)$ & $2562(2410-2690)$ \\
\hline \multirow{2}{*}{ Cephalothorax } & $\mathrm{L}$ & $1086(1020-1160)$ & $918 \quad(820-1020)$ & $1120(1000-1220)$ & $1024(820-1220)$ \\
\hline & W & $1145(1060-1330)$ & $844(780-920)$ & $1130(970-1250)$ & $1023(780-1220)$ \\
\hline Dorsal plate & W & $1281(1090-1370)$ & $1126(1020-1240)$ & $1340(860-1500)$ & $1188(1020-1240)$ \\
\hline
\end{tabular}



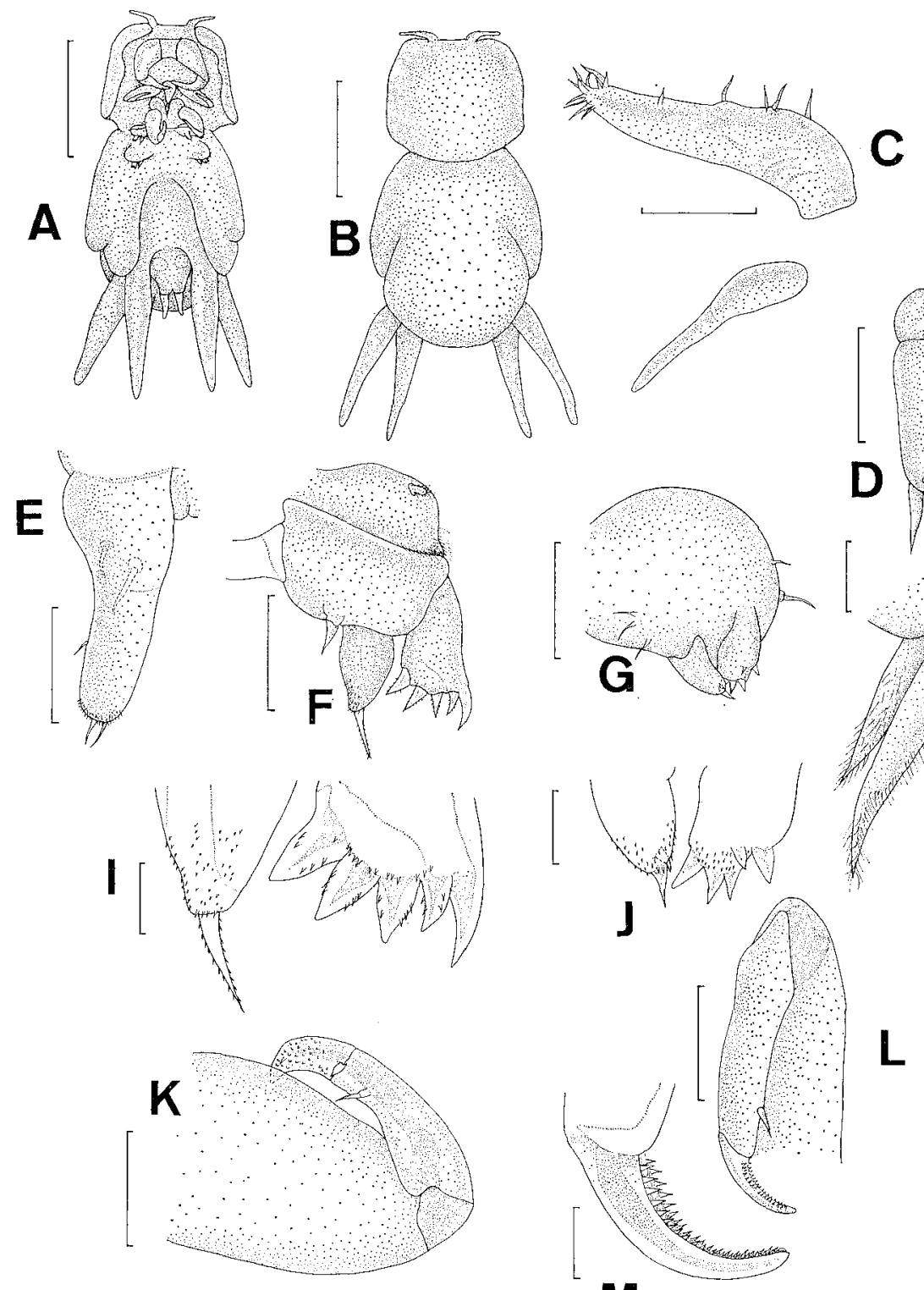

M

Fig. 4. Lernanthropus alrox Heller. Female: A. Habitus, ventral; B. Habitus, dorsal; C. First antenna, ventral; D. First maxilla, ventral; E. Caudal ramus, ventral; F. First leg, ventral; G. Second leg, ventral; H. Tip of first maxilla, ventral; I. Tip of first exopod and endopod, ventral; J. Tip of second exopod and endopod, ventral; K. Maxilliped, ventral; L. Second maxilla, ventral; M. Tip of second maxilla, ventral. Scale lines: A, B, $1000 \mu \mathrm{m} ; \mathrm{C}-\mathrm{G}, \mathrm{K}, \mathrm{L}, 100 \mu \mathrm{m} ; \mathrm{H}, \mathrm{I}, \mathrm{J}, \mathrm{M}, 25 \mu \mathrm{m}$. 
1220). Dorsal plate $1188(1020-1240)$ wide.

First antenna (Fig. 4G) short, cylindrical, with eleven naked apical setae; close to base is a two-segmented flagellum. Second antenna with single process near inner basal corner of subchela.

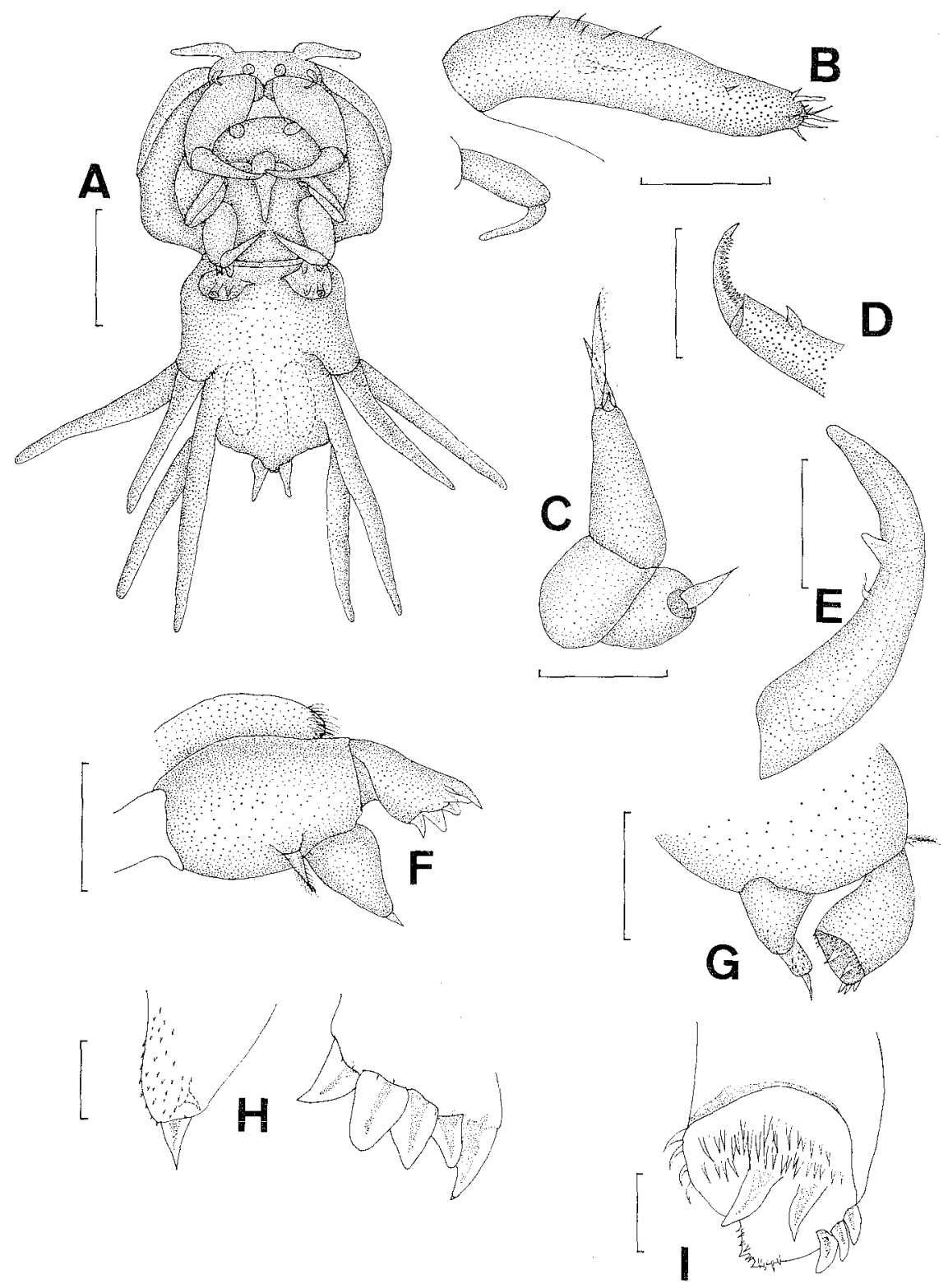

Fig. 5. Lernanthropus atrox Heller. Male: A. Habitus, ventral; B. First antenna, ventral; C. First maxilla, ventral; D. Distal tip of second maxilla, ventral; E. Distal half of maxilliped, ventral; F. First leg, ventral; G. Second leg, ventral; H. Tip of first exopod and endopod, ventral; I. Tip of second exopod, ventral. Scale lines: A, $450 \mu \mathrm{m}$; B-G, $100 \mu \mathrm{m} ; \mathrm{H}, \mathrm{I}, 25 \mu \mathrm{m}$. 
First maxilla (Fig. 4D) with subcylindrical endopod tapering slightly distally and with three terminal processes (Fig. 4H), longer two partially plumose, third short, and flattened, without plumules. Second maxilla (Fig. 4L) with robust laceratus, unarmed; brachium long, cylindrical, distally armed on posterior margin with sharp process; terminal claw (Fig. 4M) with two rows of large denticles on posterior margin.

Male (Fig. 5 A-I). Measurements based on ten specimens from Newcastle. White to yellow in preservative. Total length 1634 (1510-1730). Cephalothorax (Fig. 4A) $824(690-880) \times 962(900-1120)$. Caudal ramus 140 (100-160) long, well developed, armed as in female.

Second leg (Fig. 4G) with modified exopod (Fig. 4I) which has peduncular base, is broad distally with circular cavity at apex fringed with many denticles and five larger spines: endopod appears to be two-segmented, with short terminal seta and denticles.

Remarks. My description of both male and female are kept short because they concentrate on points either overlooked by previous authors or left ambiguous because of conflict between authors.

For example, Shiino (1955) describes only two processes at the tip of the endopod of the first maxilla; Roubal (1981) describes a third process as three-segmented; Yamaguti (1936) and I show it to be unsegmented. No previous author shows an additional subterminal spine on the endopod of leg two. Only Yamaguti and I describe two rows of denticles on the claw of the second maxilla; other authors describe only one. Also an additional mediolateral setule is described on the caudal ramus for the first time. Finally, in the male, the armature of the exopod of leg two has a total of five spines, and not a smaller number as stated by others.

L. atrox displays a wide host range, albeit all hosts are of the same familySparidae.

\author{
Genus Alella Leigh-Sharpe
}

\title{
Alella macrotrachelus (Brian)
}

\author{
(Fig. 6)
}

Clavella macrotrachelus Brian, 1906, pp. 116-117, pl. VIII, fig. 5, pl. XXI, figs 1-4; Alella macrotrachelus (Brian): Ho, 1983, pp. 46-48, figs 11-13; Alella pagelli (Krфyer, 1863): Roubal, 1981, pp. 35-36, figs 187-204; [Non] A. pagelli (Krфyer): Kabata, 1979b, pp. 413-414, figs 1975-1979.

Material examined. An unknown number of males and two thousand six hundred and ninety females collected. Hosts: A. butcheri, A. australis, A. berda and A. latus. Site: Tip of gill filaments. Localities: Coorong, Port Lincoln, Melbourne, Lakes Entrance, Swansea, Eden, Newcastle, Coffs Harbour, Brisbane, Gladstone, Townsville, Lucinda, Broome, Point Samson, and Garnarvon. See Table 8 for prevalence and relative densities; Fig. 12 for distribution.

Previous records. Roubal (1981) collected one hundred and twenty-six females and numerous males from A. australis at Coffs Harbour, N.S.W. A number of specimens were collected by Ho (1983) 
from A. schlegeli (Bleeker) at Sado Island, Japan. Brian (1906) recovered specimens from Diplodus vulgaris (Geoffroy St.-Hillaire) and D. sargus (L.) in the Mediterranean.

Female (Fig. 5 A-G). Description given by Ho (1983) requires no additions. For measurements see Tables 3 and 4.

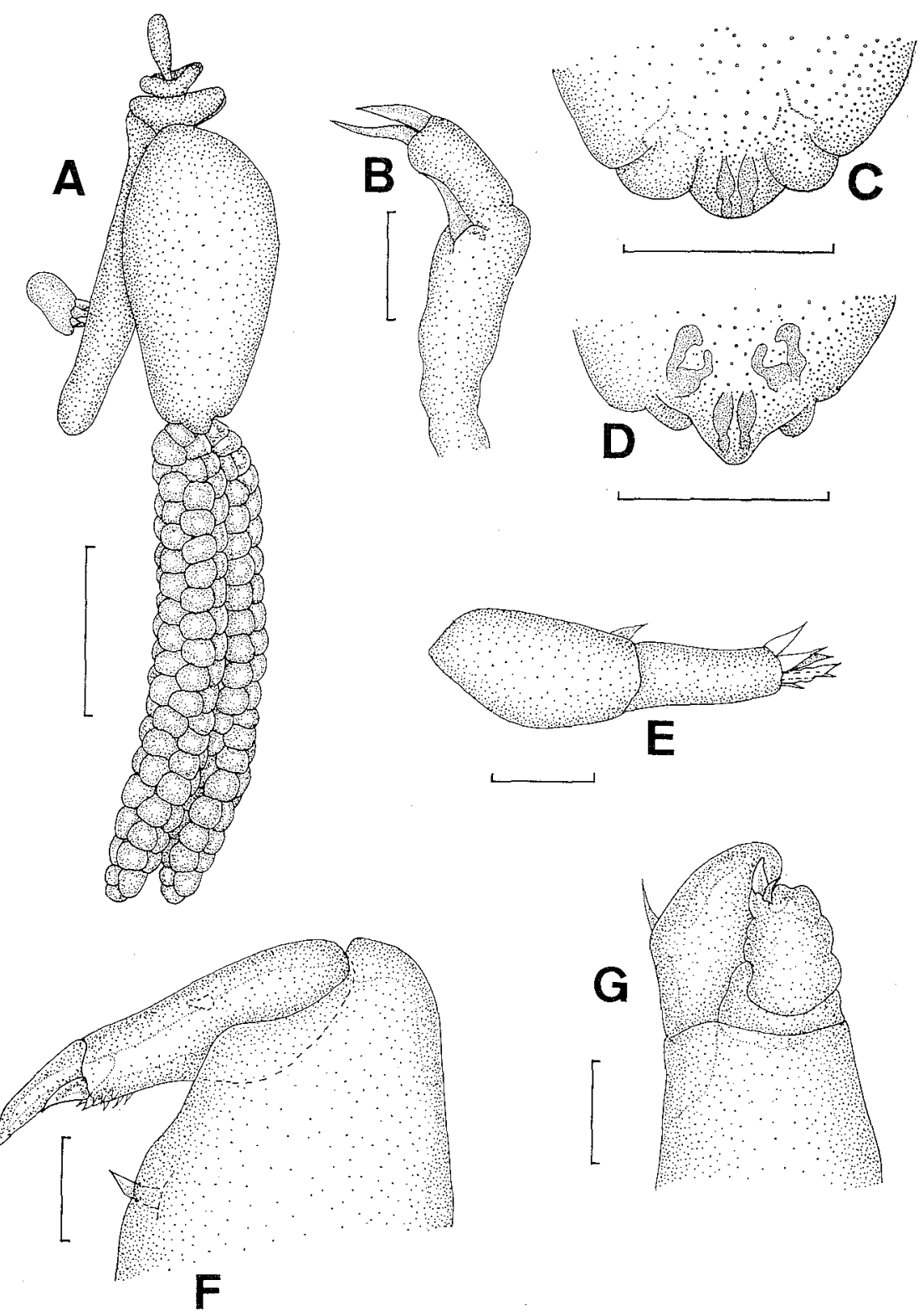

Fig. 6. Alella macrotrachelus (Brian). Female: A. Entire animal, lateral; B. Maxilla, lateral; C. Posterior portion of trunk, ventral; D. Posterior portion of trunk, dorsal; E. First antenna, ventral; F. Maxilliped, ventral; G. Second antenna, ventral. Scale lines: A, $1000 \mu \mathrm{m} ; \mathrm{B}, \mathrm{E}-\mathrm{G}, 25 \mu \mathrm{m} ; \mathrm{C}, \mathrm{D}, 100 \mu \mathrm{m}$. 
Table 3. Measurements (mean (range)) of Alella macrotrachelus 9 on two species of Acanthopagrus at various localities. ( $\mathrm{L}=$ maximum length; $\mathrm{W}=$ maximum width; $\mathrm{N}=$ number of specimens measured). Measurements of specimens from CH are according to Roubal (1981). For abbreviations of localities see Fig. 12.

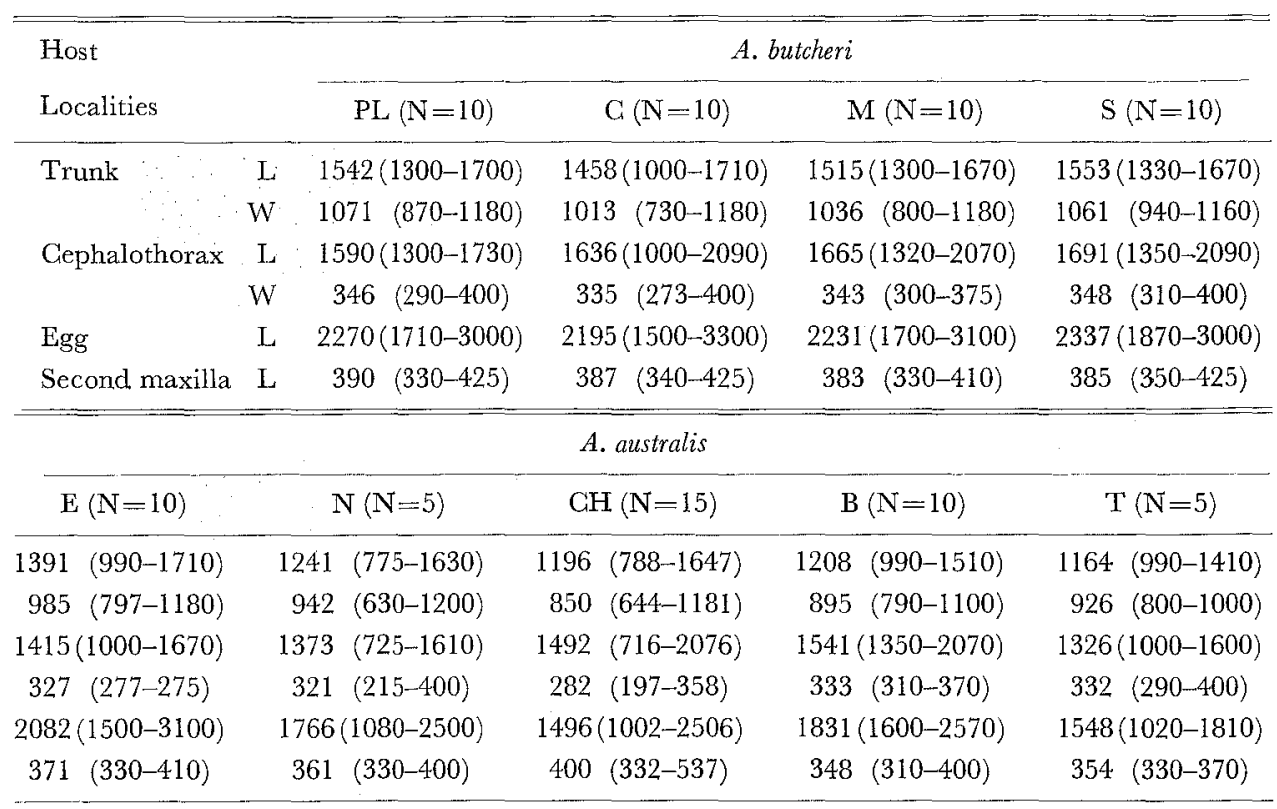

Table 4. Measurements (mean (range)) of Alella macrotrachelus $ᄋ$ on two species of Acanthopagrus at various localities. ( $\mathrm{L}=$ maximum length; $\mathrm{W}=$ maximum width; $\mathrm{N}=$ number of specimens measured). For abbreviations of localities see Fig. 12.

\begin{tabular}{|c|c|c|c|c|}
\hline \multirow{2}{*}{$\begin{array}{l}\text { Host } \\
\text { Localities }\end{array}$} & & \multirow{2}{*}{$\begin{array}{c}\text { A. berda } \\
\text { PS }(\mathrm{N}=10)\end{array}$} & \multicolumn{2}{|c|}{ A. latus } \\
\hline & & & $\mathrm{BM}(\mathrm{N}=10)$ & $\mathrm{CN}(\mathrm{N}=10)$ \\
\hline \multirow[t]{2}{*}{ Trunk } & $\mathrm{L}$ & $1256(1100-1510)$ & $1224(990-1510)$ & $1432(1100-1610)$ \\
\hline & W & $923(800-1100)$ & $939(800-1100)$ & $1019(950-1100)$ \\
\hline \multirow[t]{2}{*}{ Cephalothorax } & L & $1524(1100-2000)$ & $1490(1000-2070)$ & $1661(1000-2000)$ \\
\hline & W & $328(290-350)$ & $330(310-370)$ & $339(290-375)$ \\
\hline Egg & $\mathrm{L}$ & $1846(1500-2500)$ & $1739(1020-2500)$ & $2147(1500-3000)$ \\
\hline Second maxilla & $\mathrm{L}$ & $353(330-400)$ & $358(330-400)$ & $380(330-410)$ \\
\hline
\end{tabular}

Remarks. Kabata (1979b) considered A. macrotrachelus to be conspecific with the type species of $A$. pagelli in his redefinition of the genus Alella (see also Ho, 1983).

Although Roubal's material clearly differs from Kabata's description in possessing tubercles at the posterior end of the trunk, and in the absence of a large terminal maxilliped spine, he identified his material as A. pagelli. Nunes-Ruivo (1966), Ben Hassine et al. (1978), Kawatow et al. (1980), and Ho (1983) consider A. macrotrachelus to be a valid species. My specimens are, without doubt, the same species as Roubal's material-A. macrotrachelus examined by me. 
Genus Clavellopsis Wilson

\section{Clavellopsis parasargi Roubal}

(Figs $7 \& 8$ )

Clavellopsis parasargi Roubal, 1981, pp. 37-39, figs 205-218.

Material examined. One hundred and sixty-two females and seventy-four males collected. Hosts: A. butcheri, A. australis, and A. latus. Site: Gill arch. Localities: Eden, Newcastle, Goffs Harbour, Brisbane, Townsville, Point Samson, and Carnarvon. See Table 8 for prevalence and relative density; Fig. 12 for distribution.
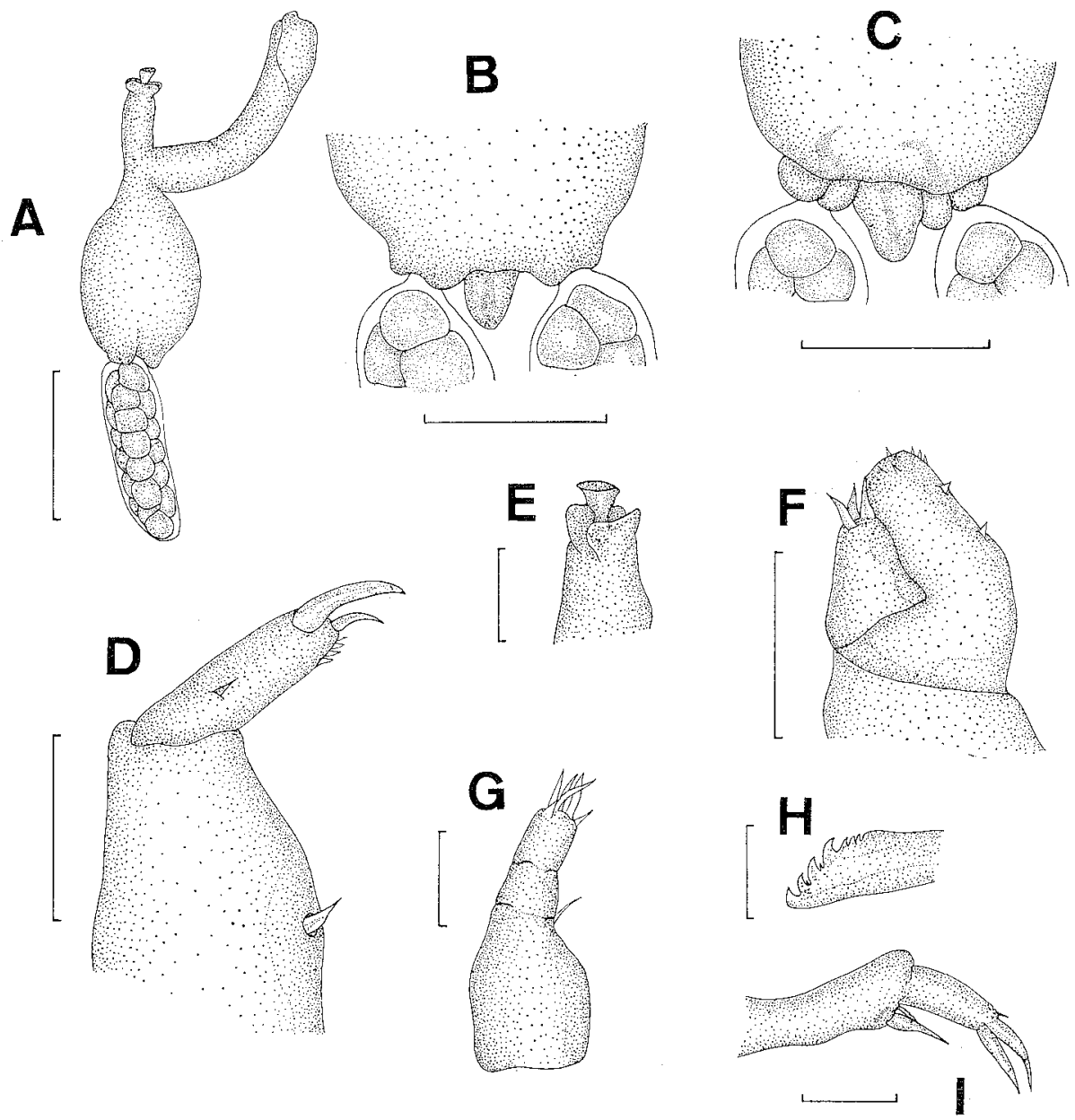

Fig. 7. Clavellopsis parasargi Roubal. Female: A. Entire animal, lateral; B. Posterior portion of trunk, ventral; C. Posterior portion of trunk, dorsal; D. Maxilliped, ventral; E. Bulla, lateral; F. Second antenna, ventral; G. First antenna, dorsal; H. Mandible, ventral; I. Maxilla, lateral. Scale lines: A, $1000 \mu \mathrm{m} ; \mathrm{B}, \mathrm{C}, 500 \mu \mathrm{m} ; \mathrm{D}, \mathrm{F}, 50 \mu \mathrm{m}$; E, $250 \mu \mathrm{m} ; \mathrm{G}-\mathrm{I}, 25 \mu \mathrm{m}$. 


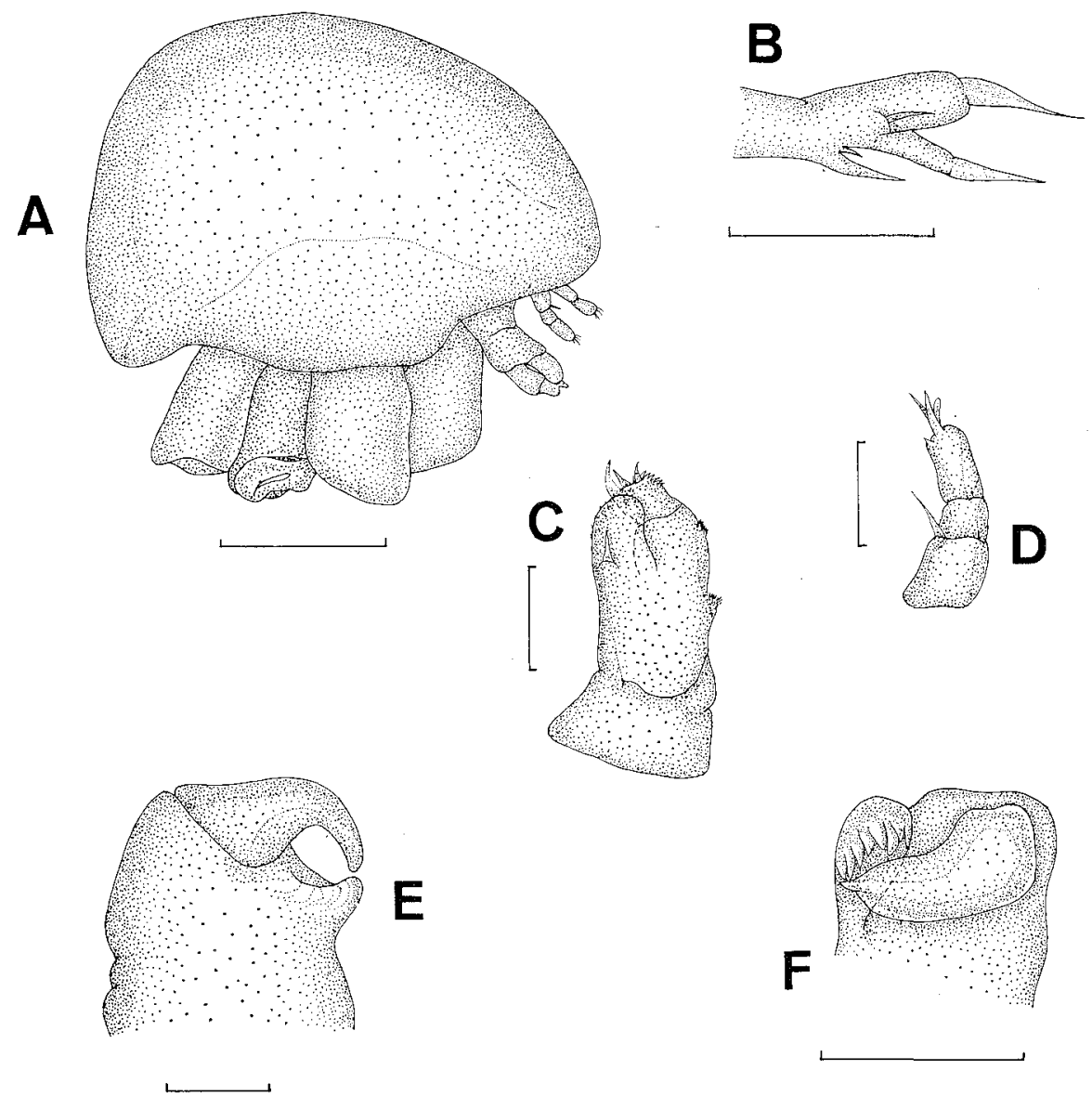

Fig. 8. Clavellopsis parasargi Roubal. Male: A. Entire animal, lateral; B. First maxilla, lateral; C. Second antenna, ventral; D. First antenna, dorsal; E. Second maxilla, ventral; F. Maxilleped, lateral. Scale lines: A, $100 \mu \mathrm{m} ; \mathrm{B}, \mathrm{F}, 50 \mu \mathrm{m} ; \mathrm{C}-\mathrm{E}, 25 \mu \mathrm{m}$.

Table 5. Measurements (mean (range)) of Clavellopsis parasargi o on two species of Acanthopagrus at various localities. ( $\mathrm{L}=$ maximum length; $\mathrm{W}=$ maximum width; $\mathrm{N}=$ number of specimens measured). Measurements of specimens from $\mathrm{CH}$ are according to Roubal (1981). For abbreviations of localities see Fig. 12.

\begin{tabular}{|c|c|c|c|c|c|}
\hline \multirow{2}{*}{$\begin{array}{l}\text { Host } \\
\text { Localities }\end{array}$} & \multirow{2}{*}{$\begin{array}{l}\text { A. butcheri } \\
\mathrm{E}(\mathrm{N}=10)\end{array}$} & \multicolumn{4}{|c|}{ A. auslralis } \\
\hline & & $\mathbf{N}(\mathbf{N}=10)$ & $\mathrm{CH}(\mathrm{N}=4)$ & $\mathrm{B}(\mathrm{N}=5)$ & $\mathrm{T}(\mathrm{N}=5)$ \\
\hline \multirow[t]{2}{*}{ Trunk } & L $1299(1100-1510)$ & $1256(1180-1350)$ & $1246(967-1360)$ & $1303(1180-1430)$ & $1216(1160-1330)$ \\
\hline & $W 1076(990-1200)$ & $1049(990-1100)$ & - & $1090(1000-1170)$ & $1030(970-1100)$ \\
\hline \multirow{2}{*}{$\begin{array}{c}\text { Cephalo- } \\
\text { thorax }\end{array}$} & L $\quad 1428(1300-1510)$ & $1396(1330-1470)$ & $1420(1324-1503)$ & $1426(1350-1490)$ & $1362(1330-1430)$ \\
\hline & $W \quad 352(330-390)$ & $339(330-360)$ & $340 \quad(322-358)$ & $352(330-370)$ & $334(310-370)$ \\
\hline Egg & L $1306(1100-1570)$ & $1232(1160-1430)$ & $1232(788-1432)$ & $1248(900-1530)$ & $1097(788-1430)$ \\
\hline $\begin{array}{l}\text { Second } \\
\text { maxilla I }\end{array}$ & $827 \quad(730-950)$ & $809(750-860)$ & $728(644-859)$ & $824(750-900)$ & $780(750-860)$ \\
\hline
\end{tabular}


Previous record. Roubal (1981) recovered eighteen specimens from A. australis at Coffs Harbour, N.S.W

Female (Fig. 7 A-I). Measurements based on ten specimens from Eden, N.S.W. For additional measurements see Table 5. Animals are white to yellow in perservative. Trunk (Fig. 7 A-C) nearly as wide as long, $1299(1100-1510) \times 1076(990-1200)$. Cephalothorax (Fig. 7A) 1428 (1300-1510) ×352 (330-390). Egg sacs nearly as long as cephalothorax. Maxilliped (Fig. 7D) robust with row of small spines near claw.

Male (Fig. 7 A-F).

Remarks. My material conforms with Roubal's (1981) description in every way except that he did not report a row of small spines near the claw of the maxilliped in the female. The presence of these spines makes $C$. parasargi even more similar to $C$. sp. from Acanthopagrus schegeli, illustrated by Roubal (1981). There still exists enough difference between the two to justify separation of the two species.

Genus Neobrachiella Kabata

Neobrachiella lata (Song et Chen)

(Figs 9-10)

Brachiella lata Song et Chen, 1976, pp. 417-418, pl. 6; Neobrachiella lata (Song et Chen) Roubal, 1981, pp. 39-41, figs 229-248.

Table 6. Measurements (mean (range)) of Neobrachiella lato on three species of Aconthopagrus at various localities. ( $\mathrm{L}=$ maximum length; $\mathrm{W}=$ maximum width; $\mathrm{N}=$ number of specimens measured). Measurements of specimens from $\mathrm{CH}$ are according to Roubal (1981). For abbreviations of localities see Fig.

\begin{tabular}{|c|c|c|c|c|c|}
\hline \multirow{2}{*}{$\begin{array}{l}\text { Host } \\
\text { Localities }\end{array}$} & \multirow{2}{*}{\multicolumn{2}{|c|}{$\begin{array}{l}\text { A. buicheri } \\
\mathrm{E}(\mathrm{N}=10)\end{array}$}} & \multicolumn{3}{|r|}{ A. berda } \\
\hline & & & $\mathrm{CH}(\mathrm{N}=12)$ & $\mathrm{B}(\mathrm{N}=5)$ & $Y(N=10)$ \\
\hline Trunk & $\mathrm{L}$ & $2492(1970-2900)$ & $2545(2327-2828)$ & $2184(1690-2730)$ & $2326(1970-2690)$ \\
\hline Dorsal process & $\mathrm{L}$ & $1782(1630-2000)$ & $1441(1074-1754)$ & $1614(1100-2000)$ & $1656(1370-2000)$ \\
\hline Ventral process & L & $1908(1790-2120)$ & $1735(1432-1969)$ & $1540(1300-1800)$ & $1623(1270-2000)$ \\
\hline Egg & ц & $4491(2900-5500)$ & $3560(2255-5012)$ & $3650(2000-5000)$ & $3684(2970-4400)$ \\
\hline \multirow[t]{2}{*}{ Cephalothorax } & $\mathrm{L}$ & $2241(1970-2900)$ & $2172(1683-2578)$ & $1834(1600-2100)$ & $1641(1450-2000)$ \\
\hline & W & $696(650-770)$ & $650(537-716)$ & $619(580-670)$ & $655(600-730)$ \\
\hline Host & & \multicolumn{2}{|l|}{ A. berda } & \multicolumn{2}{|c|}{ A. laius } \\
\hline Localities & & $\mathrm{L}(\mathrm{N}=10)$ & DW $(N=10)$ & $\mathrm{BM}(\mathrm{N}=10)$ & $\mathrm{PS}(\mathrm{N}=5)$ \\
\hline Trunk & $L$ & $2005(1880-2300)$ & $2274(1980-2600)$ & $2247(1930-2600)$ & $2290(2170-2500)$ \\
\hline Dorsal process & L & $1522(1200-1900)$ & $1563(1200-2000)$ & $1623(1290-2000)$ & $1648(1330-1900)$ \\
\hline Ventral process & $\mathrm{L}$ & $1558(1200-1900)$ & $1583(1370-1800)$ & $1696(1410-2100)$ & $1698(1410-2000)$ \\
\hline Egg & $\mathrm{L}$ & $3507(2930-4070)$ & $3489(2200-4500)$ & $4667(3570-5400)$ & $3746(2970-4400)$ \\
\hline \multirow[t]{2}{*}{ Gephalothorax } & $\mathrm{L}$ & $1392(1100-1600)$ & $1493(1330-1720)$ & $2054(1730-2500)$ & $1512(1450-1570)$ \\
\hline & W & $630(575-700)$ & $639(590-710)$ & $676(590-730)$ & $656(610-700)$ \\
\hline
\end{tabular}



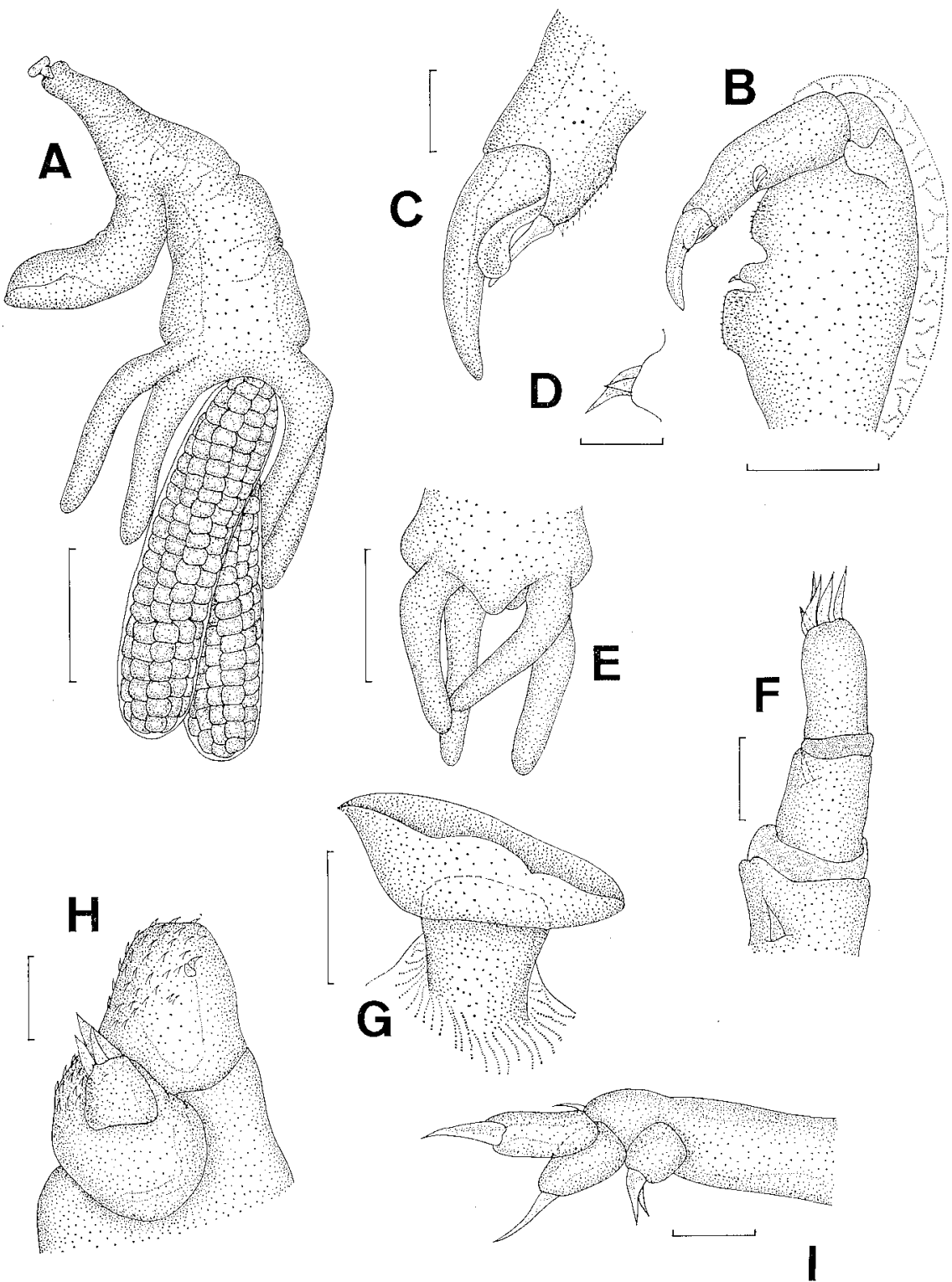

Fig. 9. Neobrachiella lata (Song et Chen). Female: A. Entire animal, lateral; B. Maxilliped, ventral; C. Distal tip of maxilliped, ventral; D. Mediolateral process of maxilliped, ventral; E. Posterior portion of trunk, ventral; F. First antenna, dorsal; G. Bulla, lateral; H. Second antenna, ventral; I. Maxilla, lateral. Scale lines: A, E, $1000 \mu \mathrm{m}$; B, G, $100 \mu \mathrm{m} ; \mathrm{C}, \mathrm{D}, \mathrm{F}, \mathrm{H}, \mathrm{I}, 50 \mu \mathrm{m}$. 
Material examined. Two hundred and forty-three females and a smaller number of males collected. Hosts: A, butcheri, A. australis, A. berda, and A. latus. Site: Mouth cavity. Localities: Eden, Coffs Harbour, Brisbane, Gladstone, Yeppoon, Townsville, Lucinda, Darwin, Broorne, and Point Samson. See Table 9 for prevalence and relative densities; Fig. 12 for distribution.

Previous records. Song \& Chen (1976) recovered a number of male and female specimens from A. latus at Hainan Dao, southern China. Roubal (1981) collected twelve female and five male specimens from $A$. australis at Coffs Harbour, N.S.W.

Female (Fig. 9 A-I). Male (Fig. $10 \mathrm{~A}-\mathrm{F}$ ). Roubal's redescription is adequate except for the minor points which are discussed below. For measurements see Table 6.
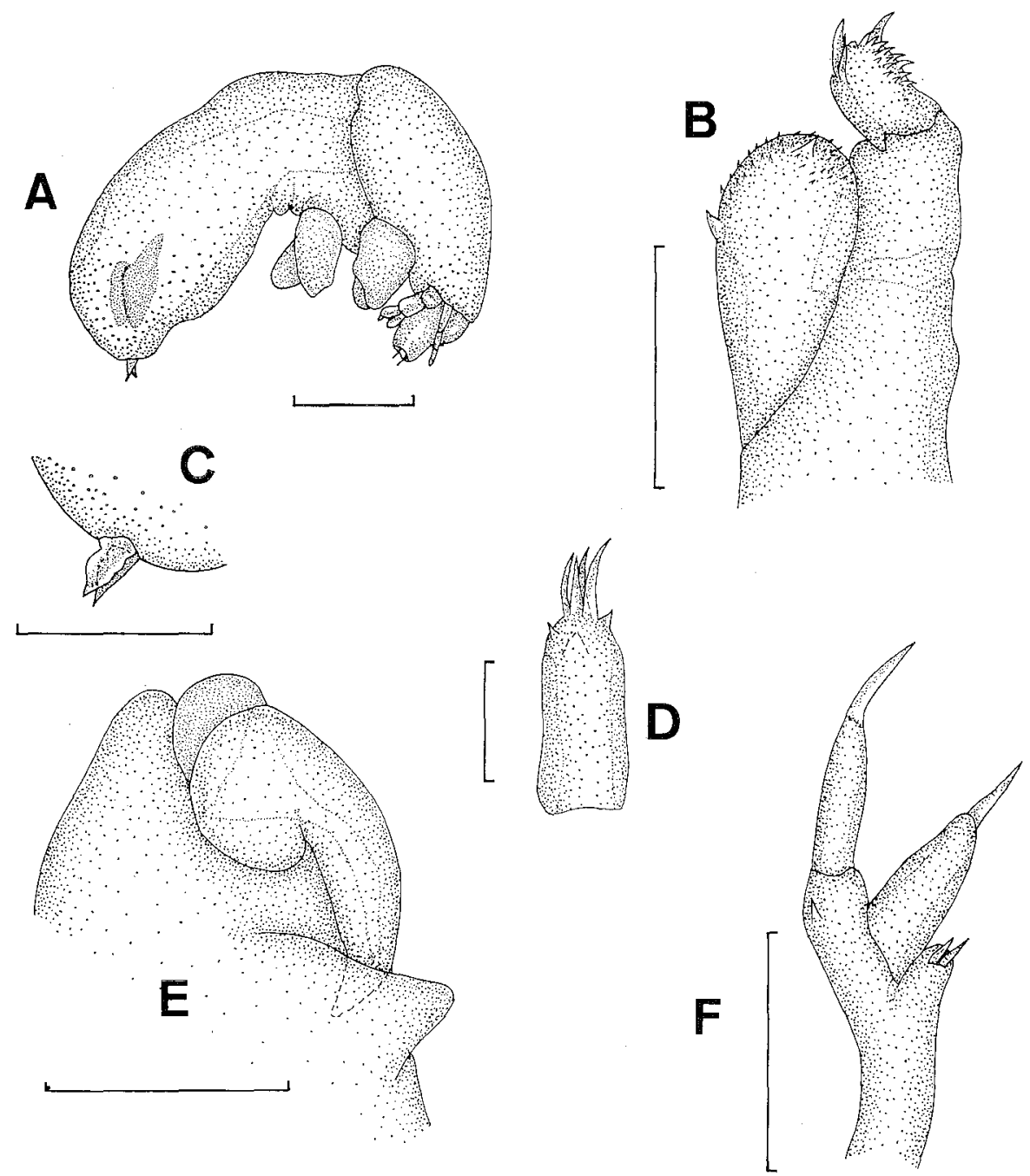

Fig. 10. Neobrachiella lata (Song et Chen). Male: A. Entire animal, lateral: B. Distal end of second antenna, ventral; C. Caudal processes, lateral; D. Distal segment of first antenna, ventral; E. Maxilliped, ventral; F. First maxilla, lateral. Scale lines: A, $250 \mu \mathrm{m} ; \mathrm{B}, \mathrm{E}, \mathrm{F}, 50 \mu \mathrm{m} ; \mathrm{C}, 100 \mu \mathrm{m} ; \mathrm{D}, 25 \mu \mathrm{m}$. 
Table 7. Lernanthropus sp., L. chrysophrys, and L. atrox. Prevalence and relative density of infection on four species of Acanthopagrus at various localities.

\begin{tabular}{|c|c|c|c|c|}
\hline Parasite species & Host species & $\begin{array}{c}\text { Locality } \\
\text { (for abbreviations } \\
\text { see Fig. 11) }\end{array}$ & Relative density & $\begin{array}{c}\text { Prevalence } \\
\%\end{array}$ \\
\hline \multirow[t]{2}{*}{$L . \mathrm{sp}$} & A. australis & $\mathrm{Y}$ & .03 & 2.5 \\
\hline & A. berda & $\mathrm{T}$ & .03 & 2.5 \\
\hline \multirow{12}{*}{ L. chrysophrys } & \multirow{4}{*}{ A. australis } & $\mathrm{T}$ & .08 & 7.5 \\
\hline & & $\mathrm{E}$ & .03 & 2.5 \\
\hline & & B & .05 & 5.0 \\
\hline & & $\mathrm{G}$ & .05 & 5.0 \\
\hline & \multirow{6}{*}{ A. berda } & $\mathrm{Y}$ & .18 & 10.0 \\
\hline & & $\mathrm{L}$ & .08 & 7.5 \\
\hline & & $\mathrm{BB}$ & .65 & 30.0 \\
\hline & & DW & .2 & 17.5 \\
\hline & & $\mathrm{BM}$ & .4 & 22.5 \\
\hline & & PS & .05 & 5.0 \\
\hline & \multirow{2}{*}{ A. latus } & $\mathrm{BM}$ & .63 & 37.5 \\
\hline & & PS & .5 & 32.5 \\
\hline \multirow{7}{*}{ L. atrox } & A. butcheri & $\mathbf{E}$ & .08 & 7.5 \\
\hline & \multirow{4}{*}{ A. australis } & $\mathrm{E}$ & .63 & 17.5 \\
\hline & & $\mathrm{N}$ & 2.1 & 50.0 \\
\hline & & $\mathrm{CH}$ & 8.0 & 65.0 \\
\hline & & B & .43 & 20.0 \\
\hline & \multirow{2}{*}{ A. latus } & $\mathrm{BM}$ & .15 & 7.5 \\
\hline & & $\mathrm{CN}$ & .03 & 2.5 \\
\hline
\end{tabular}

Remarks. My specimens are similar in most details to the material described by Roubal (1981). However, Roubal, as well as Song \& Chen (1976) failed to describe the female maxilliped correctly. These authors did not report a subterminal spine on the subchela or an additional spine near the centre of the inner margin of the basal segment (see Fig. 9 A, B and D).

\section{Host Specificity and Zoogeography}

Lernanthropus chrysophyrs was recorded from all the host species but shows a relative density and prevalence preference for $A$. berda and A. latus (see Table 7). Lernanthropus atrox infects three host species but clearly prefers $A$. australis. Because only two $L$. sp. specimens were recovered, no conclusion on its host specificity can be drawn. Alella macrotrachelus was found in large numbers on all four host species (Table 8). Clavellopsis parasargi was recorded on three bream species but it most heavily infected A. australis. Neobrachiella lata also infected four species of bream, however it showed 
Table 8. Allella macrotrachelus and Clavellopsis parasargi. Prevalence and relative density of infection on four species of Acanthopagrus at various localities.

\begin{tabular}{|c|c|c|c|c|}
\hline Parasite species & Host species & $\begin{array}{c}\text { Locality } \\
\text { (for abbreviations } \\
\text { see Fig. 11) }\end{array}$ & Relative density & $\begin{array}{c}\text { Prevalence } \\
\%\end{array}$ \\
\hline \multirow{18}{*}{ Alella macrotrachelus } & \multirow{6}{*}{ A. butcheri } & $\mathrm{C}$ & 7.4 & 75.0 \\
\hline & & PL & 1.2 & 25.0 \\
\hline & & $\mathrm{M}$ & 22.0 & 100.0 \\
\hline & & LE & 4.1 & 57.5 \\
\hline & & $\mathrm{S}$ & 11.2 & 80.0 \\
\hline & & $\mathrm{E}$ & 3.8 & 50.0 \\
\hline & \multirow{6}{*}{ A. australis } & $\mathrm{E}$ & 7.9 & 75.0 \\
\hline & & $\mathrm{N}$ & .3 & 20.0 \\
\hline & & $\mathrm{CH}$ & 3.2 & 45.5 \\
\hline & & $\mathrm{B}$ & .35 & 17.5 \\
\hline & & $\mathrm{G}$ & .08 & 7.5 \\
\hline & & $\mathrm{T}$ & .3 & 7.5 \\
\hline & \multirow{3}{*}{ A. berda } & $\mathrm{L}$ & .03 & 2.5 \\
\hline & & $\mathrm{BM}$ & 2.2 & 55.0 \\
\hline & & PS & .45 & 35.0 \\
\hline & \multirow{3}{*}{ A. latus } & $\mathrm{BM}$ & 3.9 & 90.0 \\
\hline & & PS & 6.2 & 85.0 \\
\hline & & CN & 7.1 & 90.0 \\
\hline \multirow{8}{*}{ Clavellopsis parasargi } & \multirow{2}{*}{ A. latus } & PS & .2 & 15.0 \\
\hline & & GN & .43 & 30.0 \\
\hline & A. butcheri & $\mathrm{E}$ & 1.3 & 27.5 \\
\hline & \multirow{5}{*}{ A. australis } & $\mathrm{E}$ & .7 & 27.5 \\
\hline & & $\mathrm{N}$ & 1.4 & 40.0 \\
\hline & & B & .15 & 12.5 \\
\hline & & $\mathrm{CH}$ & .82 & 31.8 \\
\hline & & $\mathrm{T}$ & .2 & 10.0 \\
\hline
\end{tabular}

strong preference for $A$. berda (see Table 9).

Both Lernanthropus atrox and L. chrysophyrs were widely distributed, which is not surprising since they have both been recorded overseas (see taxonomic section for details). Within Australia, these two parasites range from the Maugean Zoogeographical Region in the south to the Dampierian Region in the northwest (Fig. 11). Lernanthropus sp. was recovered from the Banksian Region in the northwest. Alella pagelli was collected from all zoogeographical regions and Neobrachiella lata was recovered from all but the Flindersian Region (Fig. 12). Once again, this wide Australian range was to be expected since these parasites have also been recorded overseas (see taxonomy section). Clavellopsis was also widely distributed, ranging from the Maugean Region in the south to the Dampierian Region in the northwest. 
Table 9. Neobrachiella lata. Prevalence and relative density of infection on four species of Acanthopagrus at various localities.

\begin{tabular}{|c|c|c|c|c|}
\hline Parasite species & Host species & $\begin{array}{c}\text { Locality } \\
\text { (for abbreviations } \\
\text { see Fig. 11) }\end{array}$ & Relative density & $\begin{array}{c}\text { Prevalence } \\
\%\end{array}$ \\
\hline \multirow{13}{*}{ Neobrachiella lata } & A. butcheri & $\mathrm{E}$ & .55 & 22.5 \\
\hline & \multirow{5}{*}{ A. australis } & $\mathrm{E}$ & .03 & 2.5 \\
\hline & & $\mathrm{CH}$ & .32 & 13.6 \\
\hline & & $\mathrm{B}$ & .15 & 15.0 \\
\hline & & $\mathrm{G}$ & .5 & 25.0 \\
\hline & & $\mathrm{T}$ & .15 & 7.5 \\
\hline & \multirow{5}{*}{ A. berda } & $\mathrm{Y}$ & .68 & 30.0 \\
\hline & & $\mathrm{L}$ & .58 & 37.5 \\
\hline & & DW & 1.2 & 50.0 \\
\hline & & $\mathrm{BM}$ & .68 & 35.0 \\
\hline & & PS & .08 & 5.0 \\
\hline & \multirow{2}{*}{ A. latus } & PS & .25 & 12.5 \\
\hline & & $\mathrm{BM}$ & 1.0 & 42.5 \\
\hline
\end{tabular}

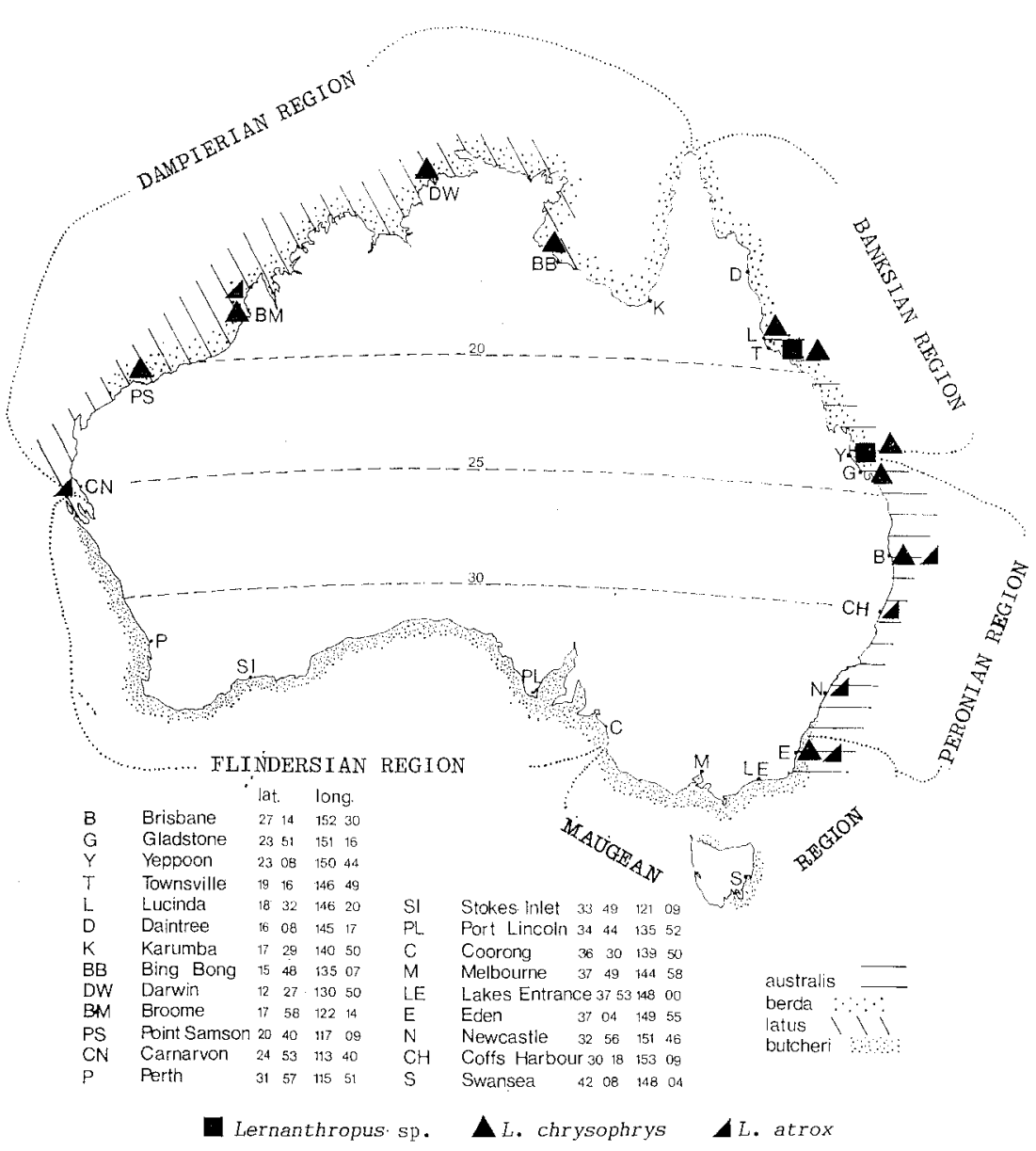

Fig. 11. Distribution of Lernanthropus sp., L. chrysophrys Shishiclo and L. atrox Heller. 


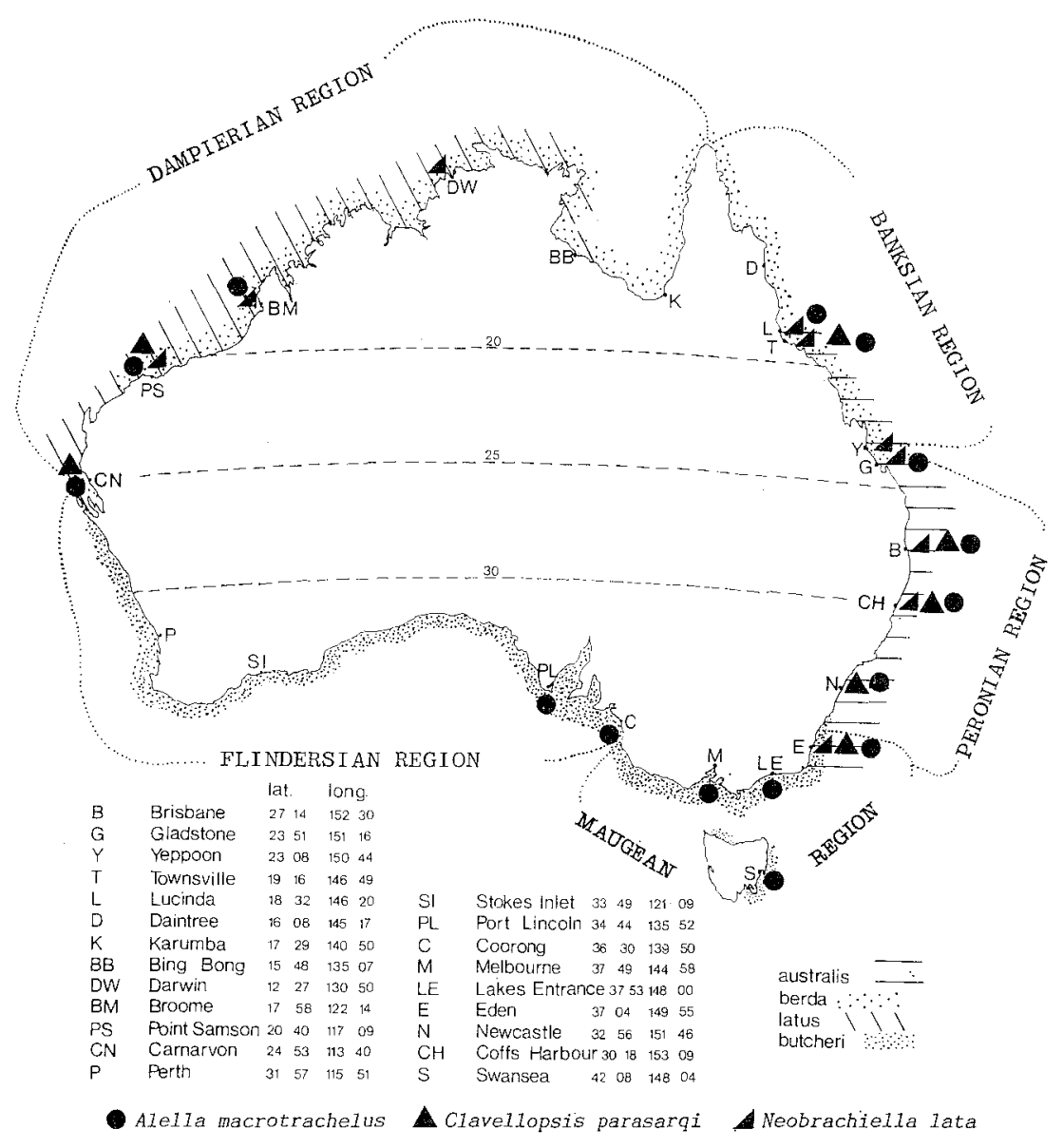

Fig. 12. Distribution of Alella macrotrachelus (Brian), Clavellopsis parasargi Roubal and Neobrachiella lata (Song et Chen).

\section{Acknowledgments}

This paper represents part of a Ph.D. thesis completed in the Zoology Department, University of New England. Advice and criticism was provided by Dr. Z. Kabata and Dr. K. Rohde. A portion of this study has been supported with an International Institute of Education Fellowship and a University of New England Scholarship. To all the above and to the many who assisted in the field, I extend my deepest gratitude.

\section{References}

Ben Hassine, O.K., K. Essafi, \& A. Raibaut 1978. Les Lernacopodidé copépods parasites de Sparidés de Tunisie. Arch. Inst. Pasteur Tunis, 55(4): 431-454.

Brian, A.G.G. 1906. Copepodi parassiti dei pesci d'Italia. 190pp. Instituto Sordomuti, Genova. Cressey, R.F. \& B.B. Collette 1970. Copepods and needlefishes: a study in host-parasite relationships.

Fish. Bull., 68: 347-432. 
Heegaard, P. 1940. Some new parasitic copepods (Chondracanthidae and Lernaeopodidae) from western Australia. Dansk Naturh. Foren. Vidensk. Med., 104: 87-101.

- 1962. Parasitic copepods from Australian waters. Rec. Aust. Mus., 25: 149-234.

Heider, C. 1879. Die Gattung Lernanthropus. Arb. Zool. Inst. Univ. Wien, 2: 269-368.

Heller, G. 1865. Crustaceen. Reise der Oesterreichischen Fregatte Novara um die Erde in den.Jahren 1857, 1858, 1859. Zool. Theil, 2(3): 1-120.

Ho, J.-S. 1983. Copepod parasites of Japanese surfperches: their inference on the phylogeny and biogeography of Embiotocidae in the Far East. Ann. Rep. Sado Mar. Biol. Stat., Niigata Univ., $13: 31-62$.

Kabata, Z. 1968. Copepods parasitic on Australian fishes. VIII. Families Lernaeopodidae and Neobranchiidae. Nat. Hist., 2: 505-523.

- 1979a. Copepoda parasitic on Australian fishes. XII. Family Lernanthropidae. Crustaceana, 37: 198-213.

- 1979b. Parasitic Copepoda of British Fishes. Pp. i-xii, 1-468, figs 1-2031. Ray Society, London.

Kawatow, K., K. Izawa \& S. Kasahara 1980. Lifecycle of Alella macrotrachelus (Copepoda) parasitic on cultured black sea bream. J. Fac. Appl. Sci., Hiroshima Univ., 19: 199-214.

Krфyer, H. 1863. Biolrag til Kundskab on Synttekrebsene. Naturh. Tid., Ser. 3, 2: 75-320.

Markevitch, A.P. \& V.M. Titar 1975. Copepod parasites of marine fishes from the Soviet Far East. In: Fourth International Congress of Parasitology. Sect. H, p. 38-39. Warszawa.

Munes-Ruivo, L.P. 1966. Le genre Alolla Leigh-Sharpe, 1925 (Copepod: Family Lernaeopodidae). Pp. 1081-1082. In: Proceeding of the First International Congress of Parasitology. A. Gorradetti, ed. 2 vols. Pergammon Press, London.

Roubal, F.R. 1981. The taxonomy and site specificity of metazoan ectoparasites on the black bream Acanthopagrus australis (Gunther) in northern New South Wales. Aust. J. Zool., Suppl., 84: 1-100.

__-_._. J. Armitage \& K. Rohde 1983. Taxonomy of metazoan ectoparasites of snapper, Chrysophyrs auratus (Family Sparidae) from southern Australia, eastern Australia and New Zealand. Ibid., Suppl., 94: 1-68.

Shiino, S.M. 1955. Copepods parasitic on Japanese fishes, VIII. The Anthosomidae. Rep. Fac. Fish., Pref. Univ. Mie, 2: 50-69.

- 1959. Sammlung der parasitischen Copepoden in der Präfekturuniversität von Mie. Ibid., 3: 334-374.

Shishido, I. 1898. Parasitic copepod, Lernanthropus. Zool. Mag. (Tokyo), 10: 120-126; 215-218; $254-256 ; 337-340$.

Song, D. \& G. Chen 1976. Some parasitic copepods from marine fish in China. Acta Zool. Sinica, 22: $406-424$.

\& P. Kuong 1980. Illustrations of the animals of China (Crustacea), 4. 90pp. Science Press, Beizing.

Tripathi, V.R. 1959 [1962]. Parasitic copepods from Indian fishes. III. Family Anothosomatidae and Dichelesthiidae. Pp. 191-217. In: Proceeding of the First All-India Congress of Zoology.

Walker, M.H. 1973. The parasites of the southern rock cod from D'Entrecastreaux Channel. Part 1. Tas. Fish. Res., 7:27-31.

Yamaguti, S. 1936. Parasitic copepods from fishes of Japan. Part 3. Caligoida, II. 21pp. Published by the author, Kyoto Imperial University. 